\title{
Foundation ownership and shareholder value: an event study
}

\section{Ann-Kristin Achleitner ${ }^{1,2} \cdot$ Dmitry Bazhutov $^{3} \cdot$ André Betzer $^{3}$ (D) Joern Block ${ }^{4,5}$. Florian Hosseini ${ }^{4}$}

Received: 3 June 2017 / Accepted: 19 July 2018 / Published online: 13 August 2018

(c) The Author(s) 2018

\begin{abstract}
Some of the largest listed firms in Western and Northern Europe are partly owned by foundations. So far, little research exists about the shareholder value effects of foundation ownership. This study aims to close this gap using an event study method. We find that equity markets show a positive reaction following the announcement by a foundation that it intends to decrease its ownership share, whereas we find no reaction when a foundation announces that it intends to increase its ownership share. The positive reaction to an announcement of an ownership share decrease is particularly strong when a foundation holds an equity stake of less than $25 \%$. Further investigations show that our findings are specific for foundations as blockholders and do not occur with other blockholders. Overall, our study shows that equity markets are skeptical about foundations as shareholders. Future research is needed to determine whether this skepticism is due to monitoring problems of foundations, goal divergences between foundations and firms, foundations being hybrid organizations with multiple goals, or legal restrictions that come with this particular form of firm ownership.
\end{abstract}

Keywords Blockholders $\cdot$ Event study $\cdot$ Foundation-owned firms $\cdot$ Shareholder value $\cdot$ Foundations

JEL Classification G32 · G34 · L21

Joern Block

block@uni-trier.de

André Betzer

betzer@wiwi.uni-wuppertal.de

1 TU Munich, Munich, Germany

2 CEFS, Munich, Germany

3 Schumpeter School of Business and Economics, University of Wuppertal, Wuppertal, Germany

4 Trier University, Trier, Germany

5 Department of Applied Economics and Erasmus Institute of Management (ERIM), Erasmus University Rotterdam, Rotterdam, The Netherlands 


\section{Introduction}

Foundation-owned firms are firms that are partly or fully owned by charitable or private foundations. In Germany, for example, more than 400 foundationowned firms exist, and a strong increase can be observed over the last 10 years (Institut für Demoskopie Allensbach 2012). Some foundation-owned firms like Bosch, Bertelsmann, and Würth, are global players and are very important for their respective regions or countries. Some of those foundation-owned firms are also listed on the stock market (e.g., Carl Zeiss, Thyssenkrupp, Erste Bank, and Kuoni).

So far, however, we know little about the shareholder value effects of foundation ownership. This is an important oversight, as foundations differ from other blockholders in important aspects. For instance, foundations usually lack residual claimants (Franke and Draheim 2015). This can result in problems monitoring the management of the firm and can increase agency costs. The lack of a residual claimant and the agency problems associated with it can also lead to a stronger stakeholder and employee orientation (Børsting and Thomsen 2017; Franke and Draheim 2015). Furthermore, foundations may face higher legal restrictions than other blockholders. In several cases, foundations are bound by their charter to always retain a majority of shares or voting rights in the firm. Finally, some foundations have charitable purposes. This can lead to conflicts of interest between the foundation's charitable and the firm's economic goals.

Our study investigates the shareholder value effects of foundation ownership. We focus on announcements made by foundations to increase or decrease their firm ownership shares and use an event study method to determine shareholder value effects. We find that equity markets show a positive reaction following a foundation's announcement to decrease its ownership share, whereas we find no reaction following a foundation's announcement to increase its ownership share. In the next step, we analyze the announcements of non-foundation blockholders in our sample of foundation-owned firms. The results show strong differences between foundation and non-foundation blockholders in the shareholder value effects of ownership share related announcements, supporting the view that equity markets view foundations as a special group of blockholders. Comparing foundation-owned firms with foundation ownership above $25 \%$ with foundationowned firms where the foundation holds less than $25 \%$ of equity, we find that the shareholder value effects of a decrease in foundation ownership are stronger in the latter group. Further robustness checks with a matched control sample of nonfoundation owned firms confirm our main results.

Our study contributes to the blockholder literature about the shareholder value effects of blockholder ownership (Morck et al. 1988; Shleifer and Vishny 1997; Thomsen et al. 2006). Prior research has not treated foundations as a separate and specific category of blockholders. We show that the shareholder value effects of foundation ownership have to be distinguished from the shareholder value effects of other forms of blockholder ownership. Our study also contributes to the small but growing literature on the performance of foundation-owned firms. Prior 
studies have investigated the accounting performance of foundation-owned firms (Dzansi 2012; Herrmann and Franke 2002; Thomsen 1996; Thomsen and Rose 2004). To the best of our knowledge, our study is the first and so far only one that focuses on the equity market performance of foundation-owned firms using an event study method. As many foundation-owned firms have hybrid goals, we also contribute to research about the performance effects of hybrid organizations (Battilana and Lee 2014; Achleitner and Block 2018).

The rest of this study proceeds as follows: Sect. 2 defines and introduces foundation-owned firms and gives a brief summary of prior research on the performance of foundation-owned firms. Section 3 develops hypotheses about the shareholder value effects of foundation ownership. Section 4 introduces our data and the event study method. Section 5 reports the results of our empirical analyses. Section 6 discusses our results and concludes.

\section{Literature review}

The literature review is comprised of three parts. The first part defines foundationowned firms as a particular group of firms and provides some background about their unique characteristics. The second part summarizes prior research about the (accounting) performance of foundation-owned firms. The third part summarizes event study results about the shareholder value effects of blockholder ownership.

\subsection{Definition and characteristics of foundation-owned firms}

Foundation-owned firms are firms that are partly or fully owned by foundations (Herrmann and Franke 2002; Thomsen 2012). The foundation is typically created by a firm's founder or founding family who transfer their equity stake into a foundation. In many cases, the foundation is created to solve firm succession problems (Fleschutz 2009). The founder may not have an appropriate heir in his or her family (Kronke 1988; Fleschutz 2009), may want to avoid or circumvent family-related succession conflicts (Davis and Harveston 2001), or does not want to sell the firm to outside investors, such as competitors or private equity firms (Klöckner 2009; Scholes et al. 2010).

Foundations are institutions without shareholders or owners. They can be subdivided into private and charitable foundations. Private foundations owning firms are typically family foundations. The main purposes of family foundations are to maintain the wealth of the founding family and to avoid family conflicts (Børsting et al. 2016; Davis and Harveston 1999, 2001). The firm distributes its dividends to the foundation, which it then distributes to the family. The family is typically represented on the foundation's board, but it no longer has a direct equity stake in the firm. The latter makes it difficult for the family to sell the firm to outside investors. The firm remains independent and avoids problems related to family conflicts. The family has however to give up some influence on the firm's management and 
strategy, as the firm is now owned and controlled by the foundation and not by the respective family.

Instead of transferring the equity into a family foundation, the founder or family may alternatively decide to transfer the equity into a charitable foundation. The foundation then uses the dividends it receives from the firm for charitable purposes, as defined in the foundation charter. The final beneficiaries of the dividends have no control or voting rights to influence the decisions of the foundation or the foundation-owned firm, which is in stark contrast to other firm owners, who are typically individuals with residual claims and control rights (Thomsen 1999). The board members of charitable foundations are typically people with a professional background in the non-profit sector. These people might be incapable of effectively monitoring the firm's management, as they may lack the entrepreneurial, industry, and management know-how needed for effective corporate governance (Franke and Draheim 2015). In such a situation, a lack of corporate control can occur, which provides opportunities for other stakeholders, such as the firm's employees or management, to pursue their own interests at the expense of the firms' development and profitability. Previous studies show that foundation-owned firms have more employees, pay higher wages, offer more secure jobs, have higher reputation, and show more responsible business behavior when compared to other firms of similar size (Franke and Draheim 2015; Børsting and Thomsen 2017). Surprisingly, however, previous studies also show that the accounting performance of foundation-owned firms is similar to other firms (Thomsen 1996, 1999; Herrmann and Franke 2002; Thomsen and Rose 2004). Classical agency theory predicting a strong underperformance of foundation-owned firms due to lack of control (leading to moral hazard and higher agency costs) seems less applicable to describe the phenomenon of foundation-owned firms. The foundation charter is an important characteristic of foundation-owned firms. The charter is influenced by the spirit and will of the founder of the foundation (and the firm) and is difficult to change after his or her death. In many cases, the foundation charter obliges the foundation to retain a majority of the firm's shares (Thomsen and Hansmann 2013). For this reason, foundation-owned firms can face problems when trying to raise equity or engage in M\&A activities. Conversely, the fact that the foundation charter is very difficult to change can be an effective protection against (hostile) takeovers (Thomsen and Rose 2004). ${ }^{1}$ This may lead to the adoption of a more long-term oriented strategy by foundation-owned firms versus other firms, which can be a benefit for shareholders and create shareholder value (Graves and Waddock 1990).

The special governance structure of foundation-owned firms together with the absence of any legal obligation for foundations to make the foundation charter publicly accessible creates a lack of transparency. This lack of transparency and the resulting uncertainty for investors presents a unique challenge for foundationowned firms listed on the stock market. Equity investors might be afraid or unwilling to invest in a firm with an uncommon and non-transparent governance and goal structure.

1 This argument does not apply when equity stake of the foundation is below $25 \%$. 


\subsection{Performance of foundation-owned firms}

Little is known about the shareholder value effects of foundation ownership in listed firms. Most prior research is about the accounting performance of foundation-owned firms. In the following, we give a brief overview of the literature on the performance of foundation-owned firms.

Thomsen (1996) is the first study that examines the performance of foundationowned firms. It compares foundation-owned firms to private firms with personal ownership and public firms with dispersed ownership. The study uses accounting data from the 300 largest companies in Denmark from 1982 to 1992 and finds no significant differences between foundation-owned firms, private firms, and public firms regarding return on assets (ROA) and return on equity (ROE). Thomsen (1999) finds that tax advantages and monitoring by minority investors and debt providers cannot explain this unexpected result. Performance increases if the family is a member of the foundation's board, but the results are not significant. There is also a tendency that publicly listed foundation-owned firms have lower ROE than nonlisted foundation-owned firms. Herrmann and Franke (2002) compare foundationowned firms to publicly listed firms using German accounting data from 1990 to 1992. They find that foundation-owned firms show a slightly higher accounting performance than listed firms. Thomsen and Rose (2004) examine the stock-market valuation of foundation-owned firms listed on the Copenhagen Stock Exchange in the period from 1996 to 1999. In a sample of 171 firms, 20 firms are majority controlled by a foundation. Their results show that listed foundation-owned firms do not differ from other listed firms regarding risk adjusted stock returns, accounting returns, and Tobin's q. In another study, Dzansi (2012) uses Stockholm Stock Exchange data of 182 firms over the period from 1999 to 2005 and compares the performance of foundation-owned firms with other firms. The study finds no effect of foundation ownership on Tobin's q. Hansmann and Thomsen (2013) take a different approach and examine the performance of different groups of Danish and Swedish foundation-owned firms over the period from 2003 to 2009. The study shows that unlisted foundation-owned firms underperform compared to listed firms when matched by industry and firm size, while listed foundation-owned firms outperform in terms of accounting returns and firm value. Franke and Draheim (2015) use a sample of 164 German firms to compare foundation-owned firms to family firms. Using accounting data from 2003 to 2012, the study shows that foundation-owned firms are larger than matched firms regarding employees, operating revenues, and total assets. Further, the study shows that foundation-owned firms pursue a more conservative financing policy, helping them to stabilize their long-term existence. The study also shows that foundation-owned firms perform slightly weaker than comparable matched firms.

\subsection{Shareholder value effects of blockholder ownership}

Blockholders are shareholders owning a substantial share of a company's stock. The exact threshold of what is considered 'substantial' varies between countries and 
their respective corporate governance systems. Two perspectives exist on the shareholder value effects of blockholder ownership: The convergence-of-interest hypothesis (Morck et al. 1988; De Miguel et al. 2004) suggests that blockholder ownership shall have a positive effect on shareholder value. In line with this argument foundations as owners shall have both the incentive and the power to effectively monitor a firm's management (Jensen and Meckling 1976; Zeckhauser and Pund 1990). The entrenchment hypothesis (Morck et al. 1988), however, suggests the opposite. Concentrated ownership may lead to an entrenchment of blockholders and managers, resulting in an expropriation of minority shareholders (Morck et al. 1988; Shleifer and Vishny 1997).

There exists an established literature using event study methods to measure the shareholder value effects of blockholder ownership. Most of these studies find a positive effect (Holderness and Sheehan 1988; Lewellen et al. 1985; Agrawal and Mandelker 1990; Barclay and Holderness 1990; Bethel et al. 1998; Holderness 2003). Some studies focus on particular types of blockholders. Achleitner et al. (2011) and Renneboog et al. (2007), for example, investigated the shareholder value effects of private equity ownership in Germany and the UK and find positive effects. Similar results are obtained for hedge funds as firm owners (Bessler et al. 2015; Brav et al. 2008). With regard to banks as blockholders, the findings are mixed. Boehmer (2000) reports that banks only have a positive effect on shareholder value if there exists a second blockholder in the firm. Regarding families as blockholders, Basu et al. (2009) and Chang et al. (2010) find that family ownership per se has a positive effect on shareholder value, which, however, reduces in situations where ownership and control are separated.

To the best of our knowledge, our study is the first one focusing on the shareholder value effects of foundation ownership using an event study method.

\section{Hypotheses about shareholder value effects of foundation ownership}

We develop two basic hypotheses about the shareholder value effects of foundation ownership. Hypothesis 1 concerns the abnormal returns following the announcement by a foundation that it intends to increase its equity stake; hypothesis 2 refers to the abnormal returns following a foundation's announcement that it intends to decrease its equity stake.

Foundations as firm owners are typically large shareholders (Dzansi 2012; Thomsen 2016). Like other blockholders, such as families or private equity firms (Maury and Pajuste 2005), foundations should have a strong incentive to monitor the firm in an efficient and effective way. They cannot easily sell their equity stake and should thus have a long-term investment horizon (Laverty 1996). These characteristics should reduce agency costs between ownership and management, thereby resulting in a positive effect on shareholder value. On the other hand, as discussed in the previous section, foundations are not the residual claimants of their ownership stake (Thomsen 1999). Foundations act on behalf of their founders, who are often no longer alive. Foundations do not use the received dividends for themselves, but rather distribute them to either charitable 
projects or to families or individual persons. Cases like this, where a residual claimant is missing, reduce the monitoring incentives for foundations and can lead to situations in which a firms' management or other stakeholders pursue their own interests, to the detriment of shareholders. In particular the stakeholder group of employees might benefit from such a situation. Prior research shows that foundation-owned firms have more employees, pay higher wages, and typically offer more secure jobs than other firms of similar size (Franke and Draheim 2015; Børsting and Thomsen 2017).

Another argument concerns the inflexible nature of foundations as shareholders. As it is difficult for foundations to sell their equity stake, and because the foundation charter typically forces them to be a majority or at least a blocking shareholder, it is difficult for foundation-owned companies to raise additional equity capital. This reduces growth possibilities for the firm and can have a negative effect on shareholder value (Agrawal and Knoeber 1996). From the firm's perspective, it can be argued that the foundation's inflexibility as shareholder provides an effective takeover defense, making the firm less likely to be a (hostile) takeover target. This situation, however, makes the stock less appealing to some investors and can lead to stock price discounts (Bebchuk et al. 2009). In other words: foundation-owned firms have a lower probability of being acquired and equity markets expect lower acquisition premiums.

Finally, foundations as firm owners are mostly unknown to equity markets, thus creating uncertainty. The institution of foundation ownership is uncommon in most countries and uncommon to most investors. This uncertainty further increases because foundations typically have a very broad and heterogeneous set of goals. Prior research shows that equity markets do not like uncertainty and put a discount on stocks associated with uncertainty (Baltussen et al. 2014).

Following this collection of arguments, we posit two hypotheses. The first hypothesis concerns the shareholder value effects (measured as abnormal returns) of an announcement by a foundation to increase its equity stake. We posit:

H1 The announcement by a foundation to increase its equity stake leads to negative abnormal returns.

The second hypothesis concerns the shareholder value effects (measured as abnormal returns) of an announcement by a foundation to decrease its equity stake. In line with the arguments above, we posit:

H2 The announcement by a foundation to decrease its equity stake leads to positive abnormal returns.

\section{Event study method}

We use the event study method to investigate how equity markets evaluate listed foundation-owned firms. In particular, we aim to identify the shareholder value effects of changes in equity stakes held by foundations in their respective firms, if any such effects exist. In comparison to regression analysis using Tobin's q as 
dependent variable, the event study approach allows us to measure the direct shareholder value effects attributed to the transaction announcements, instead of relying on a performance proxy based either on quarterly or (semi-) yearly data determined by a variety of other factors.

Following Brown and Warner $(1980,1985)$, the abnormal returns $\left(A R_{i, t}\right)$ used to capture the effects of transaction announcements are calculated by applying the market model. Hence, the expected returns of the investigated securities $\left(E\left[R_{i, t}\right]\right)$, which constitute the hypothetical returns in the absence of the event, are approximated by using a market portfolio, in our case, the S\&P Europe 350, as a comprehensive European stock market index. Assuming the market efficiency proposed by Fama (1970), we calculate the shareholder value effects of an intended change in a foundation's equity stake for a firm $i$ on day $t$ by subtracting the expected return from the actual (realized) return of the corresponding security $\left(R_{i, t}\right)$ :

$$
\begin{aligned}
& A R_{i, t}=R_{i, t}-E\left[R_{i, t}\right] \\
& E\left[R_{i, t}\right]=\hat{\alpha}_{i}+\hat{\beta}_{i} R_{M, t}
\end{aligned}
$$

We use an estimation window of 180 days (from $t=-200$ till $t=-21$ ) to obtain the OLS parameters $\hat{\alpha}_{i}$ and $\hat{\beta}_{i}$ by conducting regressions of the firm's actual returns on the market portfolio returns $\left(R_{M, t}\right)$ within this pre-event period. We define the first date on which the transaction becomes known as our event day $(t=0)$. Since we are interested in the average shareholder value effect of the announcements for our entire sample, the average abnormal return $\left(A A R_{t}\right)$ is calculated for each day $t$ of the time period surrounding the actual announcement (from $t=-20$ till $t=20$ ):

$$
A A R_{t}=\frac{1}{N} \sum_{i=1}^{N} A R_{i, t}
$$

We distinguish between two types of announcements, namely, between increases and decreases in equity stakes held by foundations. Consequently, $N$ represents the total number of announcements that refer to the aforementioned increases or decreases in foundation ownership.

In the next step, we calculate the cumulative average abnormal returns (CAAR) within the event window (from $T_{1}$ till $T_{2}$ ) in order to obtain the full average shareholder value effect for the group of foundation-owned firms:

$$
\operatorname{CAAR}_{\left[T_{1}, T_{2}\right]}=\sum_{t=T_{1}}^{T_{2}} A A R_{t}
$$

To deal with the event date uncertainty issues discussed by e.g. MacKinlay (1997), we apply several event windows around the announcement day.

The statistical significance of the obtained results is evaluated by conducting the standardized cross-sectional test of Boehmer, Musumeci, and Poulsen (BMP) 
(1991). This parametric test statistic uses the standard deviation obtained from the estimation window (adjusted for the forecasting error) to standardize the residuals, which improves the test's efficiency and power:

$$
\begin{gathered}
S A R_{i, t}=\frac{A R_{i, t}}{S_{i, t}} \\
S_{i, t}=\sqrt{\hat{\sigma}_{A R_{i}}^{2}\left[1+\frac{1}{L}+\frac{\left(R_{M, t}-\bar{R}_{M}\right)^{2}}{\sum_{t=-200}^{t=-21}\left(R_{M, t}-\bar{R}_{M}\right)^{2}}\right]}
\end{gathered}
$$

where $\hat{\sigma}_{A R_{i}}^{2}$ is the individual variance of abnormal returns derived from the estimation window, whose length is constituted by $L$.

Furthermore, in contrast to the simple $t$ test presented by Brown and Warner (1980), the BMP statistic does not assume the event-induced variance to be insignificant and, thus, it allows for respective variance changes, which may be critical for our application. Consequently, we calculate the BMP test as follows:

$$
T_{\mathrm{BMP}}=\frac{\frac{1}{N} \sum_{i=1}^{N} S A R_{i, t}}{\sqrt{\frac{1}{N(N-d)} \sum_{i=1}^{N}\left(S A R_{i, t}-\frac{1}{N} \sum_{j=1}^{N} S A R_{j, t}\right)^{2}}}
$$

where the denominator is the contemporaneous standard error and $d$ is the number of parameter estimates. In order to evaluate the null hypothesis, which states that the CAAR equals zero, the test statistic for cumulated average residuals is conducted accordingly.

For robustness purposes, we also use a non-parametric test proposed by Cowan (1992). This test (also known as the Generalized Sign (GS) test) evaluates the null hypothesis that the ratio of positive cumulative abnormal returns within the event window $\left(p_{0}^{+}\right)$does not systematically deviate from such a ratio obtained from the estimation period $\left(p_{E S T}^{+}\right)$. Taking into account a possible asymmetric distribution of excess returns, the statistic is defined as:

$$
T_{G S}=\frac{p_{0}^{+}-p_{E S T}^{+}}{\sqrt{p_{E S T}^{+}\left(1-p_{E S T}^{+}\right) / N}}
$$

The results of the BMP as well as GS test will be simultaneously reported in the next section. 


\section{Sample and results of the event study analysis}

\subsection{Sample of listed foundation-owned firms and sample of events}

The focus of our study is on the three German speaking countries Germany, Austria, and Switzerland. We started with a list of German foundation-owned firms generated from Fleschutz (2009) and Besecke (2015). Using this list, we checked the ownership structure of those firms listed in the DAX, MDAX, SDAX and TecDAX to identify all foundation-owned firms listed on the German stock market. We cross-checked and verified this sample of listed foundation-owned firms with data from the Federal Financial Supervisory Authority (BAFIN). To include listed foundation-owned firms from Austria and Switzerland in our sample, we examined the ownership structure of all companies listed on the Austrian (ATX, IATX) and Swiss (SMI, SPI, SLI) share indexes. For the identified firms, we then used the LexisNexis database and other data sources to identify relevant events referring to announcements about intended changes in foundation ownership.

Our events of interest are announcements by foundations to either increase or decrease their equity stakes in foundation-owned firms. As an example of such an event where the foundation announces its intention to increase its equity stake, consider the announcement by the Alfried Krupp von Bohlen und Halbach Stiftung (which owns Thyssenkrupp) to increase its equity stake from 20.6 to $25 \%$ (2007). Another example is the announcement of the Alfried Krupp von Bohlen und Halbach Stiftung not to participate in the firm's equity capital increase, which resulted in the foundation losing its blocking minority (2013).

Following this procedure, we were able to produce an initial sample of 83 events. These events occurred between 1993 and 2016. Because the necessary price data was missing for two of the aforementioned events, we had to drop those from our sample. Our final estimation sample thus covers 81 announcements from 29 listed foundation-owned firms. Of the 81 events, 41 events are related to announcements by foundations of increases in their equity stakes and 40 events refer to announcements about decreases in equity stakes. Table 8 in the Appendix shows the names of the firms in our sample and the corresponding events. We also denote events related to common and to preferred stock (4 events). The latter group is excluded in our comparison of shareholder value effects for foundations with above versus below $25 \%$ of equity. We also had to exclude one event where no information on the size of the equity stake was available. This yields a sample of 41 events where foundation-ownership is above $25 \%$ and 35 events where foundation-ownership is below $25 \%$.

To check the robustness of our results and to show that our results are not driven by blockholder ownership per se, we created a control sample with announcements about changes in equity stakes related to other blockholders of the foundation-owned firms investigated in our study. Other blockholders refer to other large shareholders which are not foundations. The final control sample covers 75 announcements, out of which 40 events refer to announcements by other blockholders to increase their equity stakes and 35 events relate to announcements 
Table 1 Sample description

\begin{tabular}{llll}
\hline Sample & $\begin{array}{l}\text { No. of events (all } \\
\text { announcements) }\end{array}$ & $\begin{array}{l}\text { No. of events (announcements } \\
\text { of equity stake increases) }\end{array}$ & $\begin{array}{l}\text { No. of events (announce- } \\
\text { ments of equity stake } \\
\text { decreases) }\end{array}$ \\
\hline Foundations & 81 & 41 & 40 \\
Other blockholders & 75 & 40 & 35 \\
\hline
\end{tabular}

Table 2 Event study results of main sample (foundations as shareholders)

\begin{tabular}{llll}
\hline Event window & CAAR (in \%) & $\begin{array}{l}\text { BMP test } \\
(p \text { values })\end{array}$ & $\begin{array}{l}\text { GS test } \\
(p \text { values })\end{array}$ \\
\hline
\end{tabular}

Announcements of equity stake increases (no. of events: 41)

$\begin{array}{lrll}(-3 \ldots 3) & -0.12 & 0.7163 & 0.3885 \\ (-2 \ldots 2) & 0.66 & 0.4041 & 0.1367 \\ (-1 \ldots 1) & 0.15 & 0.7473 & 0.8131 \\ (0 \ldots 0) & -0.02 & 0.9021 & 0.5827 \\ (0 \ldots 1) & 0.36 & 0.3541 & 0.5827 \\ (0 \ldots 3) & 0.67 & 0.1506 & 0.3885\end{array}$

Announcements of equity stake decreases (no. of events: 40)

\begin{tabular}{llll}
$(-3 \ldots 3)$ & 1.77 & $0.0478^{* *}$ & 0.5550 \\
$(-2 \ldots 2)$ & 2.02 & $0.0525^{*}$ & $0.0299^{* *}$ \\
$(-1 \ldots 1)$ & 0.82 & 0.3974 & $0.0299^{* *}$ \\
$(0 \ldots 0)$ & 0.27 & 0.2123 & 0.1238 \\
$(0 \ldots 1)$ & 0.81 & $0.0300^{* *}$ & $0.0636^{*}$ \\
$(0 \ldots 3)$ & 2.20 & $0.0018^{* * *}$ & $0.0299 * *$ \\
\hline$* * * p<0.01, * * p<0.05, * p<0.1$ &
\end{tabular}

about equity stake decreases. We refer to blockholders as all major shareholders that are explicitly listed as large shareholders in the company's annual report. The names of the firms and the respective events are provided in Table 9 in the "Appendix". Table 1 shows the composition of both the main and the control sample.

\subsection{Event study results for foundations as blockholders}

Table 2 reports the event study results. The second column provides the (C)AARs for six different event windows; columns 3 and 4 report the results of the BMP and GS tests, respectively.

The results show that no meaningful shareholder value effects can be observed when a foundation announces an increase in its equity stake. The stock price decreases by only $0.02 \%$ on the announcement day and by $0.12 \%$ within the 7 -day event window around the announcement. Using other event windows, such as the 3 -day event window, we find weak positive stock price reactions. These announcement effects are, however, statistically insignificant, as the results of the BMP and 
Table 3 Event study results of control sample (nonfoundation blockholders as shareholders)

\begin{tabular}{lclc}
\hline Event window & CAAR (in \%) & $\begin{array}{l}\text { BMP test } \\
(p \text { values })\end{array}$ & $\begin{array}{l}\text { GS test } \\
(p \text { values) }\end{array}$ \\
\hline \multicolumn{2}{l}{ Announcements of equity stake increases (no. of events: } & $40)$ \\
$(-3 \ldots 3)$ & 1.46 & 0.1942 & 0.8288 \\
$(-2 \ldots 2)$ & 0.64 & 0.7456 & 0.2940 \\
$(-1 \ldots 1)$ & 0.34 & 0.6934 & 0.2438 \\
$(0 \ldots 0)$ & 0.44 & $0.0660^{*}$ & 0.5943 \\
$(0 \ldots 1)$ & 1.06 & $0.0362^{* *}$ & $0.0721^{*}$ \\
$(0 \ldots 3)$ & 1.14 & $0.0499^{*} *$ & 0.2438
\end{tabular}

Announcements of equity stake decreases (no. of events: 35 )

$\begin{array}{llll}(-3 \ldots 3) & -0.58 & 0.3969 & 0.6181 \\ (-2 \ldots 2) & -0.28 & 0.7008 & 0.3920 \\ (-1 \ldots 1) & -0.33 & 0.7942 & 0.6049 \\ (0 \ldots .) & -0.34 & 0.9991 & 0.8729 \\ (0 \ldots 1) & -0.55 & 0.8513 & 0.3920 \\ (0 \ldots 3) & -0.82 & 0.3714 & 0.2397 \\ * * * p<0.01, * * p<0.05, * p<0.1 & & \end{array}$

$* * * p<0.01, * * p<0.05, * p<0.1$

GS tests show. On the other hand, the announcement by a foundation to decrease its equity stake has a statistically and economically significant effect. We find that such an announcement by a foundation leads to a CAAR of $2.20 \%$ within the event window which starts on the event day and ends three days after the announcement (BMP test is significant at $1 \%$ level; GS test is significant at 5\% level). This finding is further supported by the positive CAAR for the 7-day event window $(1.77 \%$; BMP test is significant at 5\% level), the 5-day event window (2.02\%; BMP test is significant at $10 \%$ level; GS test is significant at 5\% level), the 3-day event window $(0.82 \%$; GS test is significant at $5 \%$ level), and the 2-day event window $(0.81 \%$; BMP test is significant at 5\% level; GS test is significant at $10 \%$ level), respectively. ${ }^{2}$

\subsection{Event study results for non-foundation blockholders in foundation-owned firms}

To assess whether the ascertained announcement effects can be attributed to special characteristics of foundations as shareholders, we additionally analyze shareholder value effects related to announcements of ownership changes by other blockholders. For this purpose, we searched in our sample of foundation-owned firms for announcements by non-foundation blockholders to increase or decrease their equity stakes. As with the other event study analyses reported above, we calculate the (C) AARs for six different event windows.

\footnotetext{
${ }^{2}$ We receive qualitatively very similar results after the exclusion of 4 events (see "Appendix" for the exact events) attributed to preferred shares. The results can be obtained from the second author.
} 
Table 4 Difference-in-means test results

\begin{tabular}{llll}
\hline Event window & $\begin{array}{l}\text { CAAR (in \%) foundations } \\
\text { (no. of events: 41) }\end{array}$ & $\begin{array}{l}\text { CAAR (in \%) non-foundation } \\
\text { blockholders (no. of events: 40) }\end{array}$ & $\begin{array}{l}\text { Difference in CAAR } \\
\text { (one-sided test) }\end{array}$ \\
\hline $\begin{array}{l}\text { Announcements of equity stake increases } \\
(-3 \ldots 3)\end{array}$ & -0.12 & 1.46 & -1.58 \\
$(-2 \ldots 2)$ & 0.66 & 0.64 & 0.02 \\
$(-1 \ldots 1)$ & 0.15 & 0.34 & -0.19 \\
$(0 \ldots 0)$ & -0.02 & 0.44 & -0.46 \\
$(0 \ldots 1)$ & 0.36 & 1.06 & -0.70 \\
$(0 \ldots 3)$ & 0.67 & 1.14 & -0.47 \\
\hline Event window & CAAR (in \%) foundations & CAAR (in \%) non-foundation & Difference in CAAR \\
& (no. of events: 40) & blockholders (no. of events: 35$)$ & $($ one-sided test) \\
\hline Announcements of equity stake decreases & & $2.35^{* *}$ \\
$(-3 \ldots 3)$ & 1.77 & -0.58 & $2.30^{* *}$ \\
$(-2 \ldots 2)$ & 2.02 & -0.28 & 1.15 \\
$(-1 \ldots 1)$ & 0.82 & -0.33 & 0.61 \\
$(0 \ldots 0)$ & 0.27 & -0.34 & $1.36^{*}$ \\
$(0 \ldots 1)$ & 0.81 & -0.55 & $3.02^{* * *}$ \\
$(0 \ldots 3)$ & 2.20 & -0.82 & \\
\hline
\end{tabular}

$* * * p<0.01, * * p<0.05, * p<0.1$

Table 3 shows the results of this analysis. First of all, we find that equity stake increases announced by a non-foundation shareholder are associated with persistent positive abnormal returns. The stock price increases by $0.44 \%$ on the announcement day (BMP test is significant at $10 \%$ level), by $1.06 \%$ within the 2 -day event window (BMP test is significant at 5\% level; GS test is significant at $10 \%$ level), and even by $1.14 \%$ within the event window starting on the event day and ending three days after the announcement (BMP test is significant at 5\% level). For other event windows, the stock price reactions are also positive, but statistically insignificant. When a non-foundation blockholder in a foundation-owned firm announces that he or she will decrease his or her equity stake, negative CAARs can be observed in contrast to positive stock price reactions to such announcements made by foundations as blockholders. The negative stock price effects ascertained for other blockholders are, however, statistically insignificant for all event windows used in our study. In sum, it seems that equity markets attribute different characteristics to foundations as blockholders in comparison to other blockholders and, as a result, the announcement returns associated with changes in foundation ownership differ from those identified for non-foundation blockholders active in foundation-owned firms. 


\subsection{Difference-in-means test results}

Finally, we apply difference-in-means tests to investigate whether the divergences in stock price reactions ascertained for announcements by foundations and non-foundation blockholders to increase or decrease their equity stakes are statistically significant. Table 4 reports the results of this analysis. The second column summarizes the (C)AARs for announcements by foundations and the third column summarizes the (C) AARs for announcements by non-foundation blockholders; column 4 reports the differences between the (C)AARs for the two groups and indicates their statistical significance based on a one-sided test. With regard to announcements of increases in equity stakes, the mainly negative differences in the stock price effects, which indicate less positive or even negative announcement returns for foundations compared to other blockholders, are all insignificant. On the other hand, the persistently positive differences between the stock price reactions attributed to announcements of equity stake decreases by foundations compared to other blockholders are significant for several event windows investigated in our study. This particularly applies to the differences ascertained for the 7-day event window (2.35\%; $t$ test is significant at 5\% level), the 5-day event window $(2.30 \%$; t-test is significant at 5\% level), the 4-day event window $(3.02 \%$; t-test is significant at $1 \%$ level), and the 2-day event window (1.36\%; t-test is significant at $10 \%$ level). These results corroborate our finding that foundations are a special type of blockholder.

\subsection{Post-hoc analysis and robustness checks}

In a post hoc analysis, we distinguish between foundation-owned firms where a foundation owns an equity stake above $25 \%$ and those firms where a foundation owns less than $25 \%$ of equity. The $25 \%$ threshold refers to the situation before the announcement and the transaction. This analysis is applied to get a more detailed overview of our main results. We chose $25 \%$ as a threshold because an equity stake of more than $25 \%$ is essential for several important decisions taken at the annual shareholders' meetings of German stock companies, such as bylaw changes and capital increases ( $\$ 179$ Abs. 2,182 Abs. 1 AktG). Table 5 reports the results attributed to the respective sample split. First of all, we find that our previous results are robust and that an announcement by a foundation to decrease its equity stake has a significantly positive effect on shareholder value, both for foundation-owned firms in which a foundation holds more than $25 \%$ of firm's shares and for those in which it holds less than $25 \%$. For an announcement of a foundation to increase its ownership share, we do not find statistically significant effects in either group. The sample split also shows that the positive announcement effects of equity stake decreases are particularly strong when a foundation holds less than $25 \%$ of equity.

In a next step, we apply the $25 \%$ threshold and run a difference-in-means test comparing the shareholder value effects of foundations with those of non-foundation blockholders. We focus our analysis on announcements of equity stake decreases, as no meaningful shareholder value effects for announcements of equity stake increases by foundations were found (Table 2). Table 6 reports the results of this analysis. In sum, significant differences can be observed between foundations and non-foundation 
Table 5 Event study results of sample split (main sample)

\begin{tabular}{|c|c|c|}
\hline Event window & $\begin{array}{l}\text { CAAR (in \%) } \\
\text { under } 25 \% \text { of ownership } \\
\text { (no. of events: } 23 \text { ) }\end{array}$ & $\begin{array}{l}\text { CAAR (in \%) } \\
\text { over } 25 \% \text { of ownership } \\
\text { (no. of events: } 17 \text { ) }\end{array}$ \\
\hline \multicolumn{3}{|c|}{ Announcements of equity stake increases } \\
\hline$(-3 \ldots 3)$ & -0.56 & -0.05 \\
\hline$(-2 \ldots 2)$ & -0.10 & 1.04 \\
\hline$(-1 \ldots 1)$ & -1.37 & 1.40 \\
\hline$(0 \ldots 0)$ & -0.12 & -0.05 \\
\hline$(0 \ldots 1)$ & -0.07 & 0.37 \\
\hline$(0 \ldots 3)$ & 0.97 & 0.03 \\
\hline Event window & $\begin{array}{l}\text { CAAR (in \%) } \\
\text { under } 25 \% \text { of ownership } \\
\text { (no. of events: } 12 \text { ) }\end{array}$ & $\begin{array}{l}\text { CAAR (in \%) } \\
\text { over } 25 \% \text { of ownership } \\
\text { (no. of events: } 24 \text { ) }\end{array}$ \\
\hline \multicolumn{3}{|c|}{ Announcements of equity stake decreases } \\
\hline$(-3 \ldots 3)$ & $5.07 * *$ & -0.20 \\
\hline$(-2 \ldots 2)$ & $5.51 * * *(+)$ & 0.04 \\
\hline$(-1 \ldots 1)$ & 1.38 & 0.31 \\
\hline$(0 \ldots 0)$ & -0.63 & $0.68 * *$ \\
\hline$(0 \ldots 1)$ & -0.30 & $1.28 * * *(+)$ \\
\hline$(0 \ldots 3)$ & $3.37 * *(+)$ & $1.45^{*}$ \\
\hline
\end{tabular}

Preferred shares are excluded

BMP test $* * * p<0.01, * * p<0.05, * p<0.1$

GS test $+++p<0.01,++p<0.05,+p<0.1$

blockholders irrespective of whether blockholder ownership is above or below $25 \%$, thus supporting our previous findings. However, the result of the difference-in-means test for the blockholders with above $25 \%$ of equity should not be overinterpreted, as there are only three events referring to the group of non-foundation blockholders.

As another robustness check, we created a matched control sample of non-foundation firms with blockholder ownership of less than $25 \%$ of equity. The matched firms were selected according to the following criteria: industry, firm size (total assets), equity stake, and leverage. For those firms, we calculated the shareholder value effects following the announcement of a decrease in blockholder ownership. Using a difference-in-means test, we find significant differences in the CAARs between the two samples (Table 7) supporting our main result that equity markets are skeptical about foundations as shareholders.

\section{Discussion and conclusion}

\subsection{Summary of main results and contributions to the literature}

Based on the unique and special characteristics of foundations as shareholders, we hypothesized a negative effect of foundation ownership on shareholder value. Our 
Table 6 Difference-in-means test results of sample split

\begin{tabular}{|c|c|c|c|}
\hline $\begin{array}{l}\text { Over } 25 \% \\
\text { Event window }\end{array}$ & $\begin{array}{l}\text { CAAR (in \%) foundations } \\
\text { (no. of events: } 24 \text { ) }\end{array}$ & $\begin{array}{l}\text { CAAR (in \%) non-foundation } \\
\text { blockholders (no. of events: } 3 \text { ) }\end{array}$ & $\begin{array}{l}\text { Difference in CAAR } \\
\text { (one-sided test) }\end{array}$ \\
\hline \multicolumn{4}{|c|}{ Announcements of equity stake decreases } \\
\hline$(-3 \ldots 3)$ & -0.20 & -1.20 & 1.00 \\
\hline$(-2 \ldots 2)$ & 0.04 & -0.24 & 0.28 \\
\hline$(-1 \ldots 1)$ & 0.31 & -1.07 & 1.38 \\
\hline$(0 \ldots 0)$ & 0.68 & -2.53 & $3.21 * * *$ \\
\hline$(0 \ldots 1)$ & 1.28 & -4.66 & $5.95 * * *$ \\
\hline$(0 \ldots 3)$ & 1.45 & -5.42 & $6.87 * * *$ \\
\hline $\begin{array}{l}\text { Under } 25 \% \\
\text { Event window }\end{array}$ & $\begin{array}{l}\text { CAAR (in \%) foundations } \\
\text { (no. of events: } 12 \text { ) }\end{array}$ & $\begin{array}{l}\text { CAAR (in \%) non-foundation } \\
\text { blockholders (no. of events: } 11 \text { ) }\end{array}$ & $\begin{array}{l}\text { Difference in CAAR } \\
\text { (one-sided test) }\end{array}$ \\
\hline \multicolumn{4}{|c|}{ Announcements of equity stake decreases } \\
\hline$(-3 \ldots 3)$ & 5.07 & -1.94 & $7.01 * *$ \\
\hline$(-2 \ldots 2)$ & 5.51 & -1.53 & $7.04^{* *}$ \\
\hline$(-1 \ldots 1)$ & 1.38 & -1.03 & 2.41 \\
\hline$(0 \ldots 0)$ & -0.63 & -0.35 & -0.28 \\
\hline$(0 \ldots 1)$ & -0.30 & -0.31 & 0.01 \\
\hline$(0 \ldots 3)$ & 3.37 & -0.83 & $4.20 * *$ \\
\hline
\end{tabular}

Preferred shares are excluded

$* * * p<0.01, * * p<0.05, * p<0.1$

Table 7 Difference-in-means test results for announcements of blockholders holding less than $25 \%$ to decrease their equity stakes

\begin{tabular}{lccc}
\hline $\begin{array}{l}\text { Under 25\% } \\
\text { Event window }\end{array}$ & $\begin{array}{l}\text { CAAR (in \%) foundations } \\
\text { (no. of events: 12) }\end{array}$ & $\begin{array}{l}\text { CAAR (in \%) matched } \\
\text { firms (no. of events: 12) }\end{array}$ & $\begin{array}{l}\text { Difference in CAAR } \\
\text { (one-sided test) }\end{array}$ \\
\hline $\begin{array}{l}\text { Announcements of } \\
\text { equity stake decreases }\end{array}$ & & & \\
$(-3 \ldots 3)$ & 5.07 & -1.44 & $6.51^{* * *}$ \\
$(-2 \ldots 2)$ & 5.51 & -0.62 & $6.13^{* * *}$ \\
$(-1 \ldots 1)$ & 1.38 & -0.40 & 1.78 \\
$(0 \ldots 0)$ & -0.63 & 0.19 & -0.82 \\
$(0 \ldots 1)$ & -0.30 & -0.85 & 0.55 \\
$(0 \ldots 3)$ & 3.37 & -2.34 & $5.71^{* * *}$ \\
\hline
\end{tabular}

Preferred shares are excluded

$* * * p<0.01, * * p<0.05, * p<0.1$

empirical evidence support this hypothesis and indicates that equity markets show a positive reaction when a foundation announces that it will decrease its equity stake. This positive reaction is particularly strong when a foundation holds an equity stake of less than $25 \%$. Our results are strengthened by the fact that announcements about changes in the shareholdings of other blockholders active in our sample firms deliver opposite results. Equity markets are thus skeptical about foundations as 
blockholders and "celebrate" the news that they intend to reduce or completely sell their equity stakes. This skepticism by equity markets can be explained in different ways. Equity markets might be skeptical regarding foundations' monitoring capabilities, the goal divergences that exist between foundations and firms, the hybrid nature of the foundations' goals (Achleitner and Block 2018), or the legal restrictions that come with this particular form of firm ownership (e.g., restrictions due to the foundation's charter). Due to the foundation's strong long-term focus and emphasis of non-financial goals, there could also be severe conflicts of interest between the foundation and other (large) shareholders leading to a hitherto not analyzed form of principal-principal conflict. This conflict is particularly likely to occur when a potentially stakeholder- and employee-friendly charitable foundation meets with primarily financially motivated activist investors or hedge funds. The situation at Thyssen-Krupp, one of Germany's largest listed foundation-owned firms, is a recent example of such a principal-principal conflict. Our study is not able to tease apart these different explanations; hence, further research using larger samples and different research designs is needed (see future research below).

With these results, our study contributes to research about foundations as firm owners (e.g., Draheim 2016; Eulerich 2015; Fleschutz 2009; Herrmann 1996). We extend the literature on the performance implications of foundation ownership (e.g., Dzansi 2012; Herrmann and Franke 2002; Thomsen 1996; Thomsen and Rose 2004). To the best of our knowledge, our study is the first and only one that focuses on the equity market performance of foundation-owned firms using an event study method. Our study also adds to the broader literature about the performance consequences of blockholder ownership. The blockholder literature has focused on the performance and shareholder value effects of ownership by families (see Wagner et al. 2015 for a meta-analysis), private equity firms (e.g., Achleitner et al. 2011), banks (e.g., Lin et al. 2009), institutional investors (e.g., Mizuno 2010), and venture capital firms (e.g., Dai 2007). Our results show that foundations constitute a special type of blockholder, which has so far been overlooked. Although foundation ownership is currently still a niche phenomenon it already concerns some of the largest firms in German speaking and Scandinavian countries (e.g., Bosch, Zeiss, Ikea, and A. P. Møller-Mærsk). Furthermore, due to the fact that foundation-owned firms are frequently hold by charitable foundations, we also contribute to research about the performance effects of hybrid organizing. In organizational research, there is an ongoing discussion about how organizations can combine multiple identities, goals, and organizational cultures in one organization (Battilana and Dorado 2010; Battilana and Lee 2014; Mair et al. 2015). Our research shows that equity markets are skeptical about foundation-owned firms, which represent a special type of hybrid organization (Achleitner and Block 2018).

\subsection{Implications for practice}

Although our sample is relatively small and the phenomenon of foundation ownership is not common outside Western and Northern Europe, we formulate some tentative ideas for practical implications relating to foundations and foundation-owned firms. Based on our findings that equity markets are skeptical about foundations 
as shareholders, we suggest that foundations and foundation-owned firms need to explain the benefits of foundation ownership in a more effective way, such as by highlighting the long-term orientation afforded to the firm via foundation ownership. They may also need to be more transparent about their unique and special corporate governance structure. For many (foreign) shareholders, foundations are a "black box", which creates uncertainty about their motives and goals. Finally, our results combined with prior research about the accounting performance of foundation-owned firms (Thomsen 1996, 1999; Herrmann and Franke 2002; Thomsen and Rose 2004) imply that the stock market discount attached to some types of foundation-owned firms might not be justified. In fact, foundation-owned firms may actually be undervalued on the stock market, thereby constituting an attractive (longterm) investment.

\subsection{Limitations and avenues for further research}

Our event study suffers from two main limitations. First, we have a relatively small number of events. This is because the number of listed foundation-owned firms is still relatively small. We were also not able to find announcements of foundation equity stake changes for each listed foundation-owned firm and the public announcements of foundations to change their ownership stakes often do not contain detailed information on the respective percentage changes. The phenomenon of listed foundation-owned firms is still relatively small and young, although we believe this will change in the future as the interest in foundations as firm owners is growing steadily. Second, our results are not transferable to other countries, as the legal construct of foundation-owned firms only exists in a few, mostly European countries. Moreover, there are important differences between countries in the legal character of foundations. In the U.S., for example, private foundations or trusts are not allowed to own more than 20 percent of a firm's shares (Fleishman 2003).

Our study opens several avenues of further research. First, it would be interesting to focus on sub-samples of foundation-owned firms and compare for example the shareholder value effects of private versus charitable foundations. Such a comparison was not possible in our study due to the low number of events in either group. It could be argued that charitable foundations face greater difficulties monitoring the firm's management than private foundations. The reason is that charitable foundations typically employ and are managed by individuals with a professional background in the social or charitable sector, and therefore may not have the expertise to effectively monitor the firm's management. Private (family) foundations, in turn, are typically managed and governed by descendants of the firms' founder. Moreover, it can be argued that the two groups of foundations also differ in the degree to which they are known to capital markets. Family foundations are a common tool used to manage family wealth and are also known to US investors. Moreover, they are often regarded as a special type of family ownership (Villalonga and Amit 2008). By contrast, charitable foundations and their goals as firm owners are less known 
to equity markets outside of German speaking countries and Scandinavia. This creates uncertainty for many equity investors and can lead to a decrease in shareholder value. To summarize, we would expect listed firms owned by private foundations to be similar to listed family firms, and to be very different from foundation-owned firms owned by charitable foundations. Future research could also try to investigate why we could not observe in our data that an increase in the stake of the foundation has a negative effect on stock prices. Another direction of future research concerns the (causal) mechanism that underlies our results. Future research could try to find out why equity markets are skeptical of foundation equity ownership. For instance, is this due to foundations' monitoring problems, goal divergences between foundations and firms, foundations being hybrid organizations with multiple goals, or legal restrictions that come with this particular form of firm ownership. Future research can tackle these questions by utilizing larger samples and different research designs. Another avenue of further research would be to focus on different types of events, such as announcements about board changes in foundations. It would also be interesting to investigate our research question in a multi-country setting. Aside from German speaking countries, foundation-owned firms are also common in Scandinavia, and the BeNeLux-countries. It would be interesting to compare the shareholder value effects of foundations across countries. We would expect differences in those effects, as the legal character of foundations differs across countries. Furthermore, such an analysis based on a larger number of events resulting from more countries could allow further distinguishing between shareholder value effects of meaningful and marginal changes in foundation ownership. Moreover, the Nordic country system of corporate governance differs from the German system of corporate governance, which could affect how equity markets view foundations as firm owners. Finally, one could focus on the effects of foundation ownership on debt markets. As foundations are stable and long-term oriented firm owners, this could have positive implications for foundation-owned firms seeking funding via corporate bonds.

Acknowledgements This research was supported by a research grant from the Jackstaedt-Foundation, Wuppertal, Germany. The foundation, however, was not involved in the actual research, nor was it involved in the writing or presentation of the results. Previous versions of this paper were presented at the 21st Annual Interdisciplinary Conference on Entrepreneurship and Innovation (G-Forum) and the 16th "Hamburger Tage des Stiftungs- und Non-Profit-Rechts". The paper also benefitted from comments of the editor and three anonymous reviewers.

Open Access This article is distributed under the terms of the Creative Commons Attribution 4.0 International License (http://creativecommons.org/licenses/by/4.0/), which permits unrestricted use, distribution, and reproduction in any medium, provided you give appropriate credit to the original author(s) and the source, provide a link to the Creative Commons license, and indicate if changes were made.

\section{Appendix}

See Tables 8, 9 . 
Table 8 List of announcements of equity stake changes by foundations in foundation-owned firms

\begin{tabular}{|c|c|c|c|c|c|}
\hline ISIN & Firm & Foundation type & Date & Event * & Stake change \\
\hline DE0006275001 & Arcandor & Charitable & 06. 11. 1993 & 1 & $>20 \%$ \\
\hline DE0007686826 & Gold-Zack & Charitable & 19. 01.1996 & 0 & $>50 \%$ \\
\hline DE0005785604 & Fresenius & Charitable & 06. 05.1998 & 0 & n.a. \\
\hline DE0008051004 & Wüstenrot & Charitable & 05.11 .1998 & 1 & $>40 \%$ \\
\hline DE0007164600 & SAP & Charitable & 14. 12.1998 & 1 & n.a. \\
\hline DE0006275001 & Arcandor & Charitable & 03. 03. 1999 & 0 & $>20 \%$ \\
\hline DE0005775001 & Fränkisches Überlandwerk & Charitable & 13. 01.2000 & 0 & n.a. \\
\hline DE0008051004 & Wüstenrot & Charitable & 11. 12. 2001 & 1 & $>10 \%$ \\
\hline DE0005550636 & Drägerwerk $* *$ & Private & 19. 01.2003 & 1 & $<5 \%$ \\
\hline DE0005313704 & Zeiss & Charitable & 28. 06. 2003 & 0 & n.a. \\
\hline DE0006081003 & Holsten & Charitable & 17. 07.2003 & 0 & $<5 \%$ \\
\hline DE0005313704 & Zeiss & Charitable & 11. 12. 2003 & 0 & $<5 \%$ \\
\hline DE0006081003 & Holsten & Charitable & 28. 01.2004 & 0 & $>10 \%$ \\
\hline DE0003304002 & Software & Charitable & 14. 02.2004 & 1 & $<5 \%$ \\
\hline DE0006081003 & Holsten & Charitable & 12. 12.2003 & 1 & n.a. \\
\hline DE0005785604 & Fresenius & Charitable & 23. 05.2005 & 1 & $<5 \%$ \\
\hline AT0000834007 & Wolford & Private & 13. 09. 2005 & 1 & n.a. \\
\hline DE0005785604 & Fresenius & Charitable & 14. 10.2005 & 1 & $<5 \%$ \\
\hline DE0007500001 & Thyssenkrupp & Charitable & 29. 11. 2005 & 1 & $<5 \%$ \\
\hline DE0007572406 & Utimaco Safeware & Charitable & 15. 12. 2005 & 0 & n.a. \\
\hline DE0007500001 & Thyssenkrupp & Charitable & 29. 12. 2006 & 1 & $>5 \%$ \\
\hline AT0000818802 & $\mathrm{DO} \& \mathrm{CO}$ & Private & 29. 12. 2006 & 1 & $>50 \%$ \\
\hline CH0003504856 & Kuoni & Private & 16. 01.2007 & 0 & $<5 \%$ \\
\hline DE0005550636 & Drägerwerk $* *$ & Private & 20. 01.2007 & 0 & n.a. \\
\hline DE0008063306 & $\mathrm{IKB}$ & Charitable & 09. 03. 2007 & 1 & $<5 \%$ \\
\hline AT0000818802 & $\mathrm{DO} \& \mathrm{CO}$ & Private & 26. 03. 2007 & 0 & $<5 \%$ \\
\hline DE0003304002 & Software & Charitable & 12. 06. 2007 & 0 & n.a. \\
\hline DE0007239402 & Simona & Charitable & 23. 06. 2007 & 1 & $>10 \%$ \\
\hline DE0007500001 & Thyssenkrupp & Charitable & 03. 07. 2007 & 1 & n.a. \\
\hline DE0008063306 & IKB & Charitable & 25. 09. 2007 & 0 & n.a. \\
\hline DE0007500001 & Thyssenkrupp & Charitable & 06. 12. 2007 & 1 & $<5 \%$ \\
\hline DE0005403901 & CEWE & Private & 21. 01.2008 & 1 & n.a. \\
\hline DE0008063306 & IKB & Charitable & 11. 02. 2008 & 0 & $<5 \%$ \\
\hline DE0005313704 & Zeiss & Charitable & 11. 09. 2008 & 0 & $<5 \%$ \\
\hline AT0000937503 & Voestalpine & Private & 26. 02. 2009 & 1 & $<5 \%$ \\
\hline DE0005785604 & Fresenius & Charitable & 23. 04. 2009 & 0 & n.a. \\
\hline DE0003304002 & Software & Charitable & 01.05 .2009 & 1 & $>10 \%$ \\
\hline DE0005565204 & Dürr & Charitable & 18. 08. 2009 & 0 & n.a. \\
\hline AT0000652011 & Erste & Private & 30. 10. 2009 & 0 & $>5 \%$ \\
\hline DE0005785604 & Fresenius & Charitable & 26. 03. 2010 & 0 & n.a. \\
\hline DE0007074007 & KWS Saat & Charitable & 01.05 .2010 & 1 & $>10 \%$ \\
\hline DE0005785604 & Fresenius & Charitable & 12. 05.2010 & 1 & $<5 \%$ \\
\hline
\end{tabular}


Table 8 (continued)

\begin{tabular}{|c|c|c|c|c|c|}
\hline ISIN & Firm & Foundation type & Date & Event * & Stake change \\
\hline DE0006336100 & Kuehlhaus Zentrum & Charitable & 26. 05. 2010 & 0 & $>50 \%$ \\
\hline DE0003304002 & Software & Charitable & 10. 06. 2010 & 0 & $>20 \%$ \\
\hline DE0007239402 & Simona & Charitable & 11. 06. 2010 & 1 & n.a. \\
\hline AT0000818802 & $\mathrm{DO} \& \mathrm{CO}$ & Private & 06. 07. 2010 & 0 & $<5 \%$ \\
\hline AT0000834007 & Wolford & Private & 08. 07. 2010 & 0 & n.a. \\
\hline DE0005550636 & Drägerwerk** & Private & 15. 07. 2010 & 0 & $<5 \%$ \\
\hline AT0000818802 & DO \& CO & Private & 27. 11. 2010 & 0 & $>10 \%$ \\
\hline DE0005785604 & Fresenius & Charitable & 31. 01. 2011 & 1 & $<5 \%$ \\
\hline АT0000969985 & $\mathrm{AT} \& \mathrm{~S}$ & Private & 28.09. 2011 & 1 & n.a. \\
\hline DE0005565204 & Dürr & Charitable & 06. 12. 2011 & 1 & $<5 \%$ \\
\hline DE0005785604 & Fresenius & Charitable & 11. 05.2012 & 0 & $<5 \%$ \\
\hline DE0005785604 & Fresenius & Charitable & 03.07 .2012 & 1 & n.a. \\
\hline DE0008051004 & Wüstenrot & Charitable & 25.10 .2012 & 1 & $>10 \%$ \\
\hline AT0000937503 & Voestalpine & Private & 13. 12.2012 & 1 & n.a. \\
\hline DE0005772206 & Fielmann & Charitable & 16. 12. 2012 & 1 & n.a. \\
\hline DE0007257503 & Metro & Charitable & 18. 02.2013 & 1 & $<5 \%$ \\
\hline DE0007500001 & Thyssenkrupp & Charitable & 22. 04.2013 & 1 & $<5 \%$ \\
\hline DE0003304002 & Software & Charitable & 15. 06. 2013 & 1 & n.a. \\
\hline DE0005565204 & Dürr & Charitable & 03.07 .2013 & 0 & $<5 \%$ \\
\hline DE0005565204 & Dürr & Charitable & 05.07 .2013 & 1 & $<5 \%$ \\
\hline DE0007500001 & Thyssenkrupp & Charitable & 15. 08. 2013 & 1 & n.a. \\
\hline DE0005550636 & Drägerwerk ${ }^{* *}$ & Private & 14. 11. 2013 & 0 & n.a. \\
\hline DE0007500001 & Thyssenkrupp & Charitable & 03. 12. 2013 & 0 & n.a. \\
\hline AT0000652011 & Erste Group & Private & 05.12 .2013 & 0 & $<5 \%$ \\
\hline DE000EVNK013 & Evonik & Private & 14. 12. 2013 & 0 & $<5 \%$ \\
\hline AT0TEAKHOLZ8 & Teak Holz & Private & 29. 01.2014 & 0 & $>10 \%$ \\
\hline DE000EVNK013 & Evonik & Private & 21. 02.2014 & 0 & n.a. \\
\hline DE0005403901 & CEWE & Private & 09. 04. 2014 & 1 & $<5 \%$ \\
\hline DE0005313704 & Zeiss & Charitable & 19. 05. 2014 & 0 & n.a. \\
\hline DE000EVNK013 & Evonik & Private & 12. 02.2015 & 0 & n.a. \\
\hline AT0000937503 & Voestalpine & Private & 09.03 .2015 & 1 & n.a. \\
\hline DE0005565204 & Dürr & Charitable & 16. 03. 2015 & 1 & n.a. \\
\hline DE0003304002 & Software & Charitable & 13. 05.2015 & 1 & $<5 \%$ \\
\hline DE000EVNK013 & Evonik & Private & 21.07 .2015 & 0 & $<5 \%$ \\
\hline AT0000652011 & Erste & Private & 14. 10. 2015 & 0 & $<5 \%$ \\
\hline DE0008051004 & Wüstenrot & Charitable & 13. 11.2015 & 1 & n.a. \\
\hline AT0000818802 & $\mathrm{DO} \& \mathrm{CO}$ & Private & 01.12 .2015 & 0 & $>5 \%$ \\
\hline $\mathrm{CH} 0003504856$ & Kuoni & Private & 14. 04.2016 & 0 & $>5 \%$ \\
\hline CH0360826991 & Comet & Private & 04. 05. 2016 & 1 & $<10 \%$ \\
\hline
\end{tabular}

$* 1=$ equity stake increase, $0=$ equity stake decrease; n.a. $=$ not available

** preferred stock 
Table 9 List of announcements of equity stake changes by non-foundation blockholders in foundationowned firms

\begin{tabular}{|c|c|c|c|c|c|}
\hline ISIN & Firm & Foundation type & Date & Event * & Stake change \\
\hline DE0006275001 & Arcandor & Charitable & 28. 11. 1997 & 0 & $>10 \%$ \\
\hline DE0006275001 & Arcandor & Chartiable & 03. 03. 1998 & 1 & n.a. \\
\hline DE0006275001 & Arcandor & Charitable & 28. 07. 1998 & 0 & n.a. \\
\hline DE0006275001 & Arcandor & Charitable & 29. 07. 1999 & 0 & n.a. \\
\hline DE0005565204 & Dürr & Charitable & 25. 08. 2000 & 1 & $>5 \%$ \\
\hline DE0008051004 & Wüstenrot & Charitable & 09. 04. 2001 & 1 & $>20 \%$ \\
\hline DE0005565204 & Dürr & Charitable & 17. 01.2002 & 1 & $<5 \%$ \\
\hline DE0006275001 & Arcandor & Charitable & 03. 01.2003 & 1 & n.a. \\
\hline DE0007074007 & KWS Saat & Charitable & 15. 07. 2004 & 0 & n.a. \\
\hline DE0007074007 & KWS Saat & Charitable & 01.12 .2004 & 0 & n.a. \\
\hline DE0005785604 & Fresenius & Charitable & 15. 10. 2005 & 1 & n.a. \\
\hline DE0005565204 & Dürr & Charitable & 22. 11. 2005 & 0 & $<5 \%$ \\
\hline DE0005403901 & CEWE & Private & 10. 02. 2006 & 0 & $<5 \%$ \\
\hline DE0007164600 & SAP & Charitable & 09. 03. 2006 & 0 & n.a. \\
\hline DE0005403901 & CEWE & Private & 01. 06. 2006 & 1 & $<5 \%$ \\
\hline DE0005403901 & CEWE & Private & 18. 07. 2006 & 1 & $<5 \%$ \\
\hline DE0005403901 & CEWE & Private & 01.01 .2007 & 1 & n.a. \\
\hline DE0005403901 & CEWE & Private & 09. 02. 2007 & 1 & n.a. \\
\hline DE0005565204 & Dürr & Charitable & 17. 04. 2007 & 1 & $>5 \%$ \\
\hline DE0005565204 & Dürr & Charitable & 19. 06. 2007 & 1 & $>10 \%$ \\
\hline DE0008063306 & IKB & Charitable & 26. 06. 2007 & 1 & n.a. \\
\hline DE0005403901 & CEWE & Private & 14. 09. 2007 & 0 & n.a. \\
\hline $\mathrm{CH} 0003504856$ & Kuoni & Private & 02. 10. 2007 & 1 & n.a. \\
\hline DE0007572406 & Utimaco Safeware & Charitable & 16. 10. 2007 & 0 & n.a. \\
\hline DE0005403901 & CEWE & Private & 13. 11. 2007 & 0 & $<5 \%$ \\
\hline CH0003504856 & Kuoni & Private & 05. 12. 2007 & 1 & n.a. \\
\hline DE0005772206 & Fielmann & Charitable & 10. 12. 2007 & 1 & n.a. \\
\hline CH0003504856 & Kuoni & Private & 05. 02. 2008 & 0 & n.a. \\
\hline $\mathrm{CH} 0003504856$ & Kuoni & Private & 28. 03. 2008 & 0 & n.a. \\
\hline DE0008063306 & $\mathrm{IKB}$ & Charitable & 09. 04. 2008 & 0 & n.a. \\
\hline CH0003504856 & Kuoni & Private & 21. 07. 2008 & 1 & n.a. \\
\hline DE0008063306 & IKB & Charitable & 20. 08. 2008 & 1 & $>40 \%$ \\
\hline DE0008063306 & IKB & Charitable & 17. 09. 2008 & 0 & $>50 \%$ \\
\hline DE0005565204 & Dürr & Charitable & 29. 10. 2008 & 1 & $>5 \%$ \\
\hline $\mathrm{CH} 0003504856$ & Kuoni & Private & 04. 05. 2009 & 1 & n.a. \\
\hline DE0008051004 & Wüstenrot & Charitable & 18. 07. 2009 & 0 & $<5 \%$ \\
\hline DE0005565204 & Dürr & Charitable & 18. 08. 2009 & 1 & n.a. \\
\hline AT0000652011 & Erste & Private & 17. 11. 2009 & 1 & n.a. \\
\hline DE0006336100 & Kuehlhaus Zentrum & Charitable & 22. 12.2009 & 0 & n.a. \\
\hline DE0003304002 & Software & Charitable & 30. 03. 2010 & 1 & n.a. \\
\hline DE0005565204 & Dürr & Charitable & 01.10 .2010 & 0 & $<5 \%$ \\
\hline
\end{tabular}


Table 9 (continued)

\begin{tabular}{|c|c|c|c|c|c|}
\hline ISIN & Firm & Foundation type & Date & Event * & Stake change \\
\hline CH0003504856 & Kuoni & Private & 05.11 .2010 & 1 & n.a. \\
\hline DE0003304002 & Software & Charitable & 10.01. 2011 & 0 & $<5 \%$ \\
\hline DE0005565204 & Dürr & Charitable & 17. 02. 2011 & 0 & $>10 \%$ \\
\hline CH0003504856 & Kuoni & Private & 13. 08. 2012 & 1 & n.a. \\
\hline DE0008051004 & Wüstenrot & Charitable & 06.09 .2012 & 0 & $>5 \%$ \\
\hline DE0005772206 & Fielmann & Charitable & 15. 11. 2012 & 1 & $>10 \%$ \\
\hline АT0000937503 & Voestalpine & Private & 04. 12. 2012 & 0 & n.a. \\
\hline DE0005772206 & Fielmann & Charitable & 10. 01.2013 & 0 & $>20 \%$ \\
\hline DE0007500001 & Thyssenkrupp & Charitable & 25. 09. 2013 & 1 & n.a. \\
\hline $\mathrm{CH} 0003504856$ & Kuoni & Private & 04. 10. 2013 & 0 & n.a. \\
\hline DE0007164600 & SAP & Charitable & 29. 10. 2013 & 0 & n.a. \\
\hline CH0003504856 & Kuoni & Private & 29. 10. 2013 & 0 & n.a. \\
\hline АT0000937503 & Voestalpine & Private & 04.11 .2013 & 1 & n.a. \\
\hline DE0007500001 & Thyssenkrupp & Charitable & 20.11. 2013 & 1 & $>5 \%$ \\
\hline $\mathrm{CH} 0003504856$ & Kuoni & Private & 17. 12.2013 & 0 & n.a. \\
\hline AT0000937503 & Voestalpine & Private & 02.01 .2014 & 0 & n.a. \\
\hline AT0TEAKHOLZ8 & Teak Holz & Private & 17. 01.2014 & 1 & n.a. \\
\hline DE0007500001 & Thyssenkrupp & Charitable & 05. 03. 2014 & 1 & $>5 \%$ \\
\hline DE0003304002 & Software & Charitable & 15. 05. 2014 & 1 & $<5 \%$ \\
\hline DE0003304002 & Software & Charitable & 10.06. 2014 & 0 & $<5 \%$ \\
\hline DE0003304002 & Software & Charitable & 23. 06. 2014 & 1 & $<5 \%$ \\
\hline AT0000937503 & Voestalpine & Private & 06.11 .2014 & 1 & n.a. \\
\hline AT0000937503 & Voestalpine & Private & 23. 12.2014 & 0 & n.a. \\
\hline DE0007164600 & SAP & Charitable & 25.11 .2015 & 1 & n.a. \\
\hline CH0360826991 & Comet & Private & 22. 12. 2015 & 1 & n.a. \\
\hline CH0360826991 & Comet & Private & 08. 03. 2016 & 0 & n.a. \\
\hline СH0003504856 & Kuoni & Private & 14. 04.2016 & 1 & n.a. \\
\hline CH0003504856 & Kuoni & Private & 02.05 .2016 & 1 & n.a. \\
\hline CH0360826991 & Comet & Private & 05.05 .2016 & 0 & n.a. \\
\hline CH0360826991 & Comet & Private & 07. 06. 2016 & 0 & n.a. \\
\hline DE0007500001 & Thyssenkrupp & Charitable & 27. 06. 2016 & 1 & n.a. \\
\hline AT0000834007 & Wolford & Private & 14. 11. 2016 & 0 & n.a. \\
\hline СH0360826991 & Comet & Private & 19. 04. 2017 & 1 & n.a. \\
\hline CH0360826991 & Comet & Private & 19. 05. 2017 & 0 & n.a. \\
\hline
\end{tabular}

$* 1=$ equity stake increase, $0=$ equity stake decrease; n.a. $=$ not available 


\section{References}

Achleitner AK, Block JH (2018) Stiftungsunternehmen als hybride Organisationen an der Schnittstelle zwischen Gewinn- und Gemeinwohlorientierung. In: Achleitner AK, Block JH, Strachwitz R (eds) Stiftungsunternehmen: theorie und Praxis. Springer, Wiesbaden

Achleitner AK, Andres C, Betzer A, Weir C (2011) Wealth effects of private equity investments on the German stock market. Eur J Financ 17(3):217-239

Agrawal A, Knoeber CR (1996) Firm performance and mechanisms to control agency problems between managers and shareholders. J Financ Quant Anal 31(3):377-397

Agrawal A, Mandelker GN (1990) Large shareholders and the monitoring of managers: the case of antitakeover charter amendments. J Financ Quant Anal 25(2):143-161

Baltussen G, van Bekkum S, van der Grient B (2014) Unknown unknowns: uncertainty about risk and stock returns. AFA 2013 San Diego meetings paper

Barclay MJ, Holderness CG (1990) Negotiated block trades and corporate control. J Financ 46(3):861-878

Basu N, Dimitrova L, Paeglis I (2009) Family control and dilution in mergers. J Bank Financ 33(5):829-841

Battilana J, Dorado S (2010) Building sustainable hybrid organizations: the case of commercial microfinance organizations. Acad Manag J 53(6):1419-1440

Battilana J, Lee M (2014) Advancing research on hybrid organizing-insights from the study of social enterprises. Acad Manag Ann 8(1):397-441

Bebchuk L, Cohen A, Ferrell A (2009) What matters in corporate governance? Rev Financ Stud 22(2):783-827

Besecke MK (2015) Essays on family- and foundation-owned firms. Dissertation. Technische Universität München

Bessler W, Drobetz W, Holler J (2015) The returns to hedge fund activism in Germany. Eur Financ Manag 21(1):106-147

Bethel JF, Porter J, Opler T (1998) Block share purchases and corporate performance. J Financ 53(1):605-634

Boehmer E (2000) Business groups, bank control, and large shareholders: an analysis of German takeovers. J Financ Intermed 9(2):117-148

Boehmer E, Musumeci JJ, Poulsen AB (1991) Event study methodology under conditions of event induced variance. J Financ Econ 30(2):253-272

Børsting C, Thomsen S (2017) Foundation ownership, reputation, and labour. Oxford Rev Econ Pol 33(2):317-338

Børsting C, Kuhn J, Poulsen T, Thomsen S (2016) Long-term ownership by industrial foundations. Asian Finance Association Conference

Brav A, Jiang W, Partnoy F, Thomas R (2008) Hedge fund activism, corporate governance, and firm performance. J Financ 63(4):1729-1775

Brown S, Warner J (1980) Measuring security price performance. J Financ Econ 8(3):205-258

Brown S, Warner J (1985) Using daily stock returns: the case of event studies. J Financ Econ 14(1):3-31

Chang SC, Wu WY, Wong YJ (2010) Family control and stock market reactions to innovation announcements. Br J Manag 21(1):152-170

Cowan AR (1992) Nonparametric event study tests. Rev Quant Finance Account 2(4):353-371

Dai N (2007) Does investor identity matter? An empirical examination of investments by venture capital funds and hedge funds in PIPEs. J Corp Financ 13(4):538-563

Davis PS, Harveston PD (1999) In the founder's shadow: conflict in the family firm. Fam Bus Rev 12(4):311-323

Davis PS, Harveston PD (2001) The phenomenon of substantive conflict in the family firm: a cross-generational study. J Small Bus Manag 39(1):14-30

De Miguel A, Pindado J, de la Torre C (2004) Ownership structure and firm value: new evidence from Spain. Strateg Manag J 25(12):1199-1207

Draheim M (2016) Three essays on foundation owned firms in Germany. Dissertation. Universität Konstanz

Dzansi J (2012) Foundation control and investment performance: do intrinsic aspects of ownership and control matter? Glob Econ Financ J 5(2):58-78

Eulerich M (2015) Stiftungsverbundene Unternehmen in Deutschland. Erich Schmidt Verlag, Berlin 
Fama EF (1970) Efficient capital markets: a review of theory and empirical work. J Financ 25(2):383-417

Fleishman JL (2003) Stiftungsführung und Unternehmenskontrolle in Deutschland und den Vereinigten Staaten: Die Bedeutung von Unabhängigkeit und Freiheit der Stiftungen für das Gemeinwohl. In: Stiftung Bertelsmann (ed) Handbuch Stiftungen, 2nd edn. Gabler, Wiesbaden, pp 352-391

Fleschutz K (2009) Die Stiftung als Nachfolgeinstrument für Familienunternehmen. Gabler, Wiesbaden

Franke G, Draheim M (2015) Foundation owned firms in Germany-a field experiment for agency theory. Beiträge zur Jahresgestaltung des Vereins für Socialpolitik 2015: Ökonomische EntwicklungTheorie und Politik. Session: Financial Economics IV

Graves SB, Waddock SA (1990) Institutional ownership and control: implications for long-term corporate stragey. Acad Manag Exec 4(1):75-83

Hansmann H, Thomsen S (2013) Managerial distance and virtual ownership: The governance of industrial foundations. ECGI-Finance Working Paper No. 372, Yale Law \& Economics Research Paper No. 467

Herrmann M (1996) Unternehmenskontrolle durch Stiftungen—Untersuchung der Performancewirkungen. Gabler, Wiesbaden

Herrmann M, Franke G (2002) Performance and policy of foundation-owned firms in Germany. Eur Financ Manag 8(3):261-279

Holderness C (2003) A survey of blockholders and corporate control. Econ Policy Rev 9(1):51-63

Holderness C, Sheehan D (1988) The role of majority shareholders in public held corporations. J Financ Econ 20(1):317-346

Institut für Demoskopie Allensbach (2012) Stiftungsunternehmen in Deutschland. BDO AG. http://epub. sub.uni-hamburg.de/epub/volltexte/2015/37546/pdf/Allensbach_Studie.pdf. Accessed 03 Jan 2018

Jensen MC, Meckling WH (1976) Theory of the firm: managerial behavior, agency costs and ownership structure. J Financ Econ 3(4):305-360

Klöckner O (2009) Buy-outs in family businesses. Gabler, Wiesbaden

Kronke H (1988) Stiftungstypus und Unternehmensträgerstiftung: Eine rechtsvergleichende Untersuchung. Mohr Siebeck, Tübingen

Laverty KJ (1996) Economic "short termism": the debate, the unresolved issues, and the implications for management practice and research. Acad Manage Rev 21(3):825-860

Lewellen W, Loderer C, Rosenfeld A (1985) Merger decisions and executive stock ownership in acquiring firms. J Account Econ 7(1-3):209-231

Lin X, Yi Z, Ning Z (2009) Does bank ownership increase firm value? Evidence from China. J Int Money Financ 28(4):720-737

MacKinlay AC (1997) Event studies in economics and finance. J Econ Lit 35(1):13-39

Mair J, Mayer J, Lutz E (2015) Navigating institutional plurality: organizational governance in hybrid organizations. Organ Stud 36(6):713-739

Maury B, Pajuste A (2005) Multiple large shareholders and firm value. J Bank Financ 29(7):1813-1834

Mizuno M (2010) Institutional investors, corporate governance and firm performance in Japan. Pac Econ Rev 15(5):653-665

Morck R, Shleifer A, Vishny RW (1988) Management, ownership and market valuation: an empirical analysis. J Financ Econ 20:293-315

Renneboog L, Simons T, Wright M (2007) Why do public firms go private in the UK? The impact of private equity investors, incentive realignment and undervaluation. J Corp Financ 13(4):591-628

Scholes L, Wright M, Westhead P, Bruining H (2010) Strategic changes in family firms post management buyout: ownership and governance issues. Int Small Bus J 28(5):505-521

Shleifer A, Vishny RW (1997) A survey of corporate governance. J Financ 52(2):737-783

Thomsen S (1996) Foundation ownership and economic performance. Corp Gov 4(4):212-221

Thomsen S (1999) Corporate ownership by industrial foundations. Eur J Law Econ 7(2):1095-1117

Thomsen S (2012) What do we know (and not know) about industrial foundations. Working Paper

Thomsen S (2016) The Nordic corporate governance model. Manag Organ Rev 12(1):189-204

Thomsen S, Hansmann H (2013) The performance of foundation-owned companies. Working Paper

Thomsen S, Rose C (2004) Foundation ownership and financial performance: do companies need owners? Eur J Law Econ 18(3):343-364

Thomsen S, Pedersen T, Kvist HK (2006) Blockholder ownership: effects on firm value in market and control based governance systems. J Corp Financ 12(2):246-269

Villalonga B, Amit R (2008) How are U.S. family firms controlled? Rev Financ Stud 22(8):3047-3091

Wagner D, Block JH, Miller D, Schwens C, Xi G (2015) A meta-analysis of the financial performance of family firms: another attempt. J Fam Bus Strateg 6(1):3-13 
Zeckhauser RJ, Pund J (1990) Are large shareholders effective monitors? An investigation of share ownership and corporate performance. In: Hubbard RG (ed) Asymmetric information, corporate finance and investment. University of Chicago Press, Chicago, pp 149-180 